\title{
SYNTHESIS AND BIOLOGICAL ACTIVITIES OF 7-ALKOXYMITOSANES
}

\author{
Chikahiro Urakawa and Kin-ICHI NAKANO \\ Tokyo Research Laboratory of Kyowa Hakko Kogyo Co., Ltd. \\ 3-6-6 Asahimachi, Machidashi, Tokyo, Japan \\ RYOJI IMAI \\ Pharmaceutical Research Laboratories of Kyowa Hakko Kogyo Co., Ltd. \\ 1188 Shimotogari, Nagaizumicho, Suntogun, Shizuoka, Japan \\ (Received for publication May 9, 1980)

\begin{abstract}
A facile alcoholysis of 7-methoxymitosanes and 5-methoxyindolequinone under basic conditions was discovered and a series of 7 -alkoxymitosanes were synthesized from mitomycins $\mathrm{A}$ and $\mathrm{B}$ using this reaction. They showed strong antibacterial activity against various Grampositive and Gram-negative bacteria and were potent inhibitors of cultivating HeLa S-3 cells in vitro. Among them, 7-n-propoxy-7-demethoxymitomycin A (2) showed the strongest antitumor activity against solid type Sarcoma-180 in mice.
\end{abstract}

Since mitomycins A and B were found in a culture broth of Streptomyces caespitosus in 1956, ${ }^{1)}$ many studies have been carried out on a group of mitomycins which includes the well-known antitumor antibiotic, mitomycin C. ${ }^{2)}$ The mitomycins, including their derivatives, can be classified into two groups mitosanes and mitosenes. ${ }^{3)}$ Among the mitosane group, mitomycin $\mathrm{A}$ has the greatest antibacterial activity against various bacteria and is the most cytotoxic. Therefore, it has been suggested that mitomycin A analogs such as 7-alkoxymitosanes are interesting derivatives. Although there are some reports on the preparation of 7-alkoxymitosanes, those processes consist of two-steps and are low-yield synthetic methods due to the alkylation of unstable 7-hydroxymitosane intermediates by diazoalkanes. Furthermore, no biological activities of the 7-alkoxymitosanes have been investigated. ${ }^{4,5}$ )

The preparation of various 7-alkoxymitosanes might be a logical approach for the synthesis of potentially potent chemotherapeutic agents. With this goal in mind we have developed useful one-step synthesis of various 7-alkoxymitosanes from naturally occurring mitomycins having 7-methoxy substituents. The present report describes the synthesis and biological evaluation of various 7-alkoxymitosanes.

$\begin{array}{lllll} & \mathrm{X} & \mathrm{Z} & \\ \text { Mitomycin } \mathrm{A} & \mathrm{CH}_{3} \mathrm{O} & \mathrm{H} & \\ \text { Mitomycin } \mathrm{C} & \mathrm{NH}_{2} & \mathrm{H} & \\ \text { Porfiromycin } & \mathrm{NH}_{2} & \mathrm{CH}_{3} & \text { Mitomycin B } & \text { Mitosane structure }\end{array}$




\section{Chemistry}

In the presence of small amounts of a base, 7-methoxymitosanes underwent alcoholysis and were converted to the corresponding 7-alkoxymitosanes. The reaction was carried out in a short period when the 7-methoxymitosanes were dissolved in alcohol in the presence of a base such as sodium alkoxide or potassium hydroxide with stirring at room temperature.

The reactions with mitomycin A or B and various alcohols yielded the corresponding 7-alkoxymitosanes. They are 7-ethoxy (1), 7-n-propoxy (2), 7-i-propoxy (3), 7-n-butoxy (4), 7-i-butoxy (5), 7-secbutoxy (6), 7-n-amyloxy (7), 7-i-amyloxy (8), 7-n-hexyloxy (9), 7-cyclohexyloxy (10), 7-n-heptyloxy (11), 7-n-octyloxy (12), 7-n-decyloxy (13), 7-stearyloxy (14), 7-(2-methoxy)ethoxy (15), and 7-benzyloxy-7demethoxymitomycin A (16) and 7-i-propoxy-7-demethoxymitomycin B (17).

Fig. 1. Alcoholysis of mitomycins $\mathrm{A}$ and $\mathrm{B}$ and indolequinone.
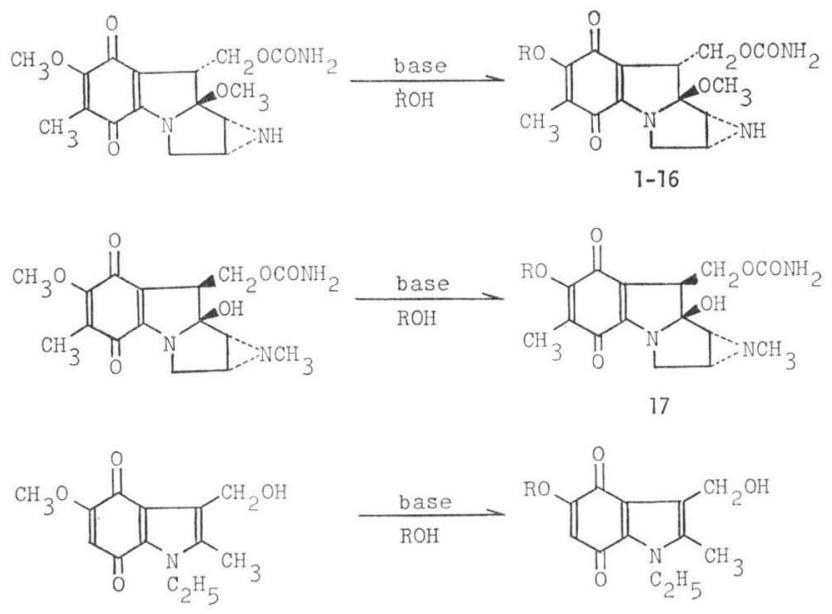

18

Table 1. Properties and yields of mitomycin 7-alkoxy derivatives and a related compound.

\begin{tabular}{|c|c|c|c|c|c|c|}
\hline \multicolumn{2}{|r|}{ Product* } & \multirow{2}{*}{ Base } & \multirow{2}{*}{$\begin{array}{l}\text { Yield } \\
\%\end{array}$} & \multirow{2}{*}{$\underset{{ }^{\circ} \mathrm{C} \text { (dec.) }}{\mathrm{Mp}}$} & \multicolumn{2}{|l|}{$\mathrm{M}^{+}$} \\
\hline No. & RO & & & & Calcd. & Found \\
\hline 1 & $\mathrm{CH}_{3} \mathrm{CH}_{2} \mathrm{O}$ & $\mathrm{KOH}$ & 97.3 & $143 \sim 150$ & $363.1430\left(\mathrm{C}_{17} \mathrm{H}_{21} \mathrm{~N}_{3} \mathrm{O}_{6}\right)$ & 363.1430 \\
\hline 2 & $\mathrm{CH}_{3}\left(\mathrm{CH}_{2}\right)_{2} \mathrm{O}$ & $\mathrm{CH}_{3}\left(\mathrm{CH}_{2}\right)_{2} \mathrm{ONa}$ & 85.7 & $148 \sim 157$ & $377.1587\left(\mathrm{C}_{18} \mathrm{H}_{23} \mathrm{~N}_{3} \mathrm{O}_{8}\right)$ & 377.1541 \\
\hline 3 & $\left(\mathrm{CH}_{3}\right)_{2} \mathrm{CHO}$ & $\left(\mathrm{CH}_{3}\right)_{2} \mathrm{CHONa}$ & 78.5 & $170 \sim 183$ & $377.1587\left(\mathrm{C}_{18} \mathrm{H}_{23} \mathrm{~N}_{3} \mathrm{O}_{6}\right)$ & 377.1557 \\
\hline 4 & $\mathrm{CH}_{3}\left(\mathrm{CH}_{2}\right)_{3} \mathrm{O}$ & $\mathrm{KOH}$ & 69.6 & $130 \sim 140$ & $391.1743\left(\mathrm{C}_{19} \mathrm{H}_{25} \mathrm{~N}_{3} \mathrm{O}_{6}\right)$ & 391.1826 \\
\hline 5 & $\left(\mathrm{CH}_{3}\right)_{2} \mathrm{CHCH}_{2} \mathrm{O}$ & $\mathrm{KOH}$ & 75.4 & powder & $391.1743\left(\mathrm{C}_{19} \mathrm{H}_{25} \mathrm{~N}_{3} \mathrm{O}_{6}\right)$ & 391.1758 \\
\hline 7 & $\mathrm{CH}_{3}\left(\mathrm{CH}_{2}\right)_{4} \mathrm{O}$ & $\mathrm{KOH}$ & 49.7 & $106 \sim 112$ & $405.1900\left(\mathrm{C}_{20} \mathrm{H}_{27} \mathrm{~N}_{3} \mathrm{O}_{6}\right)$ & 405.1826 \\
\hline 8 & $\left(\mathrm{CH}_{3}\right)_{2} \mathrm{CHCH}_{2} \mathrm{CH}_{2} \mathrm{O}$ & $\mathrm{KOH}$ & 71.7 & powder & $405.1900\left(\mathrm{C}_{20} \mathrm{H}_{27} \mathrm{~N}_{3} \mathrm{O}_{6}\right)$ & 405.1758 \\
\hline 9 & $\mathrm{CH}_{3}\left(\mathrm{CH}_{2}\right)_{5} \mathrm{O}$ & $\mathrm{KOH}$ & 36.6 & $105 \sim 116$ & $419.2056\left(\mathrm{C}_{21} \mathrm{H}_{29} \mathrm{~N}_{3} \mathrm{O}_{6}\right)$ & 419.2138 \\
\hline 11 & $\mathrm{CH}_{3}\left(\mathrm{CH}_{2}\right)_{6} \mathrm{O}$ & $\mathrm{KOH}$ & 57.0 & $102 \sim 108$ & $433.2212\left(\mathrm{C}_{22} \mathrm{H}_{31} \mathrm{~N}_{3} \mathrm{O}_{6}\right)$ & 433.2190 \\
\hline 12 & $\mathrm{CH}_{3}\left(\mathrm{CH}_{2}\right)_{7} \mathrm{O}$ & $\mathrm{KOH}$ & 56.1 & $110 \sim 112$ & $447.2369\left(\mathrm{C}_{23} \mathrm{H}_{33} \mathrm{~N}_{3} \mathrm{O}_{6}\right)$ & 447.2397 \\
\hline 13 & $\mathrm{CH}_{3}\left(\mathrm{CH}_{2}\right)_{9} \mathrm{O}$ & $\mathrm{KOH}$ & 57.3 & $113 \sim 117$ & $475.2682\left(\mathrm{C}_{25} \mathrm{H}_{37} \mathrm{~N}_{3} \mathrm{O}_{6}\right)$ & 475.2680 \\
\hline 15 & $\mathrm{CH}_{3} \mathrm{OCH}_{2} \mathrm{CH}_{2} \mathrm{O}$ & $\mathrm{KOH}$ & 48.8 & powder & $393.1536\left(\mathrm{C}_{18} \mathrm{H}_{23} \mathrm{~N}_{3} \mathrm{O}_{7}\right)$ & 393.1570 \\
\hline 16 & $\mathrm{C}_{6} \mathrm{H}_{5} \mathrm{CH}_{2} \mathrm{O}$ & $\mathrm{KOH}$ & 49.9 & $139 \sim 146$ & $425.1587\left(\mathrm{C}_{22} \mathrm{H}_{23} \mathrm{~N}_{3} \mathrm{O}_{6}\right)$ & 425.1611 \\
\hline 17 & $\left(\mathrm{CH}_{3}\right)_{2} \mathrm{CHO}$ & $\left(\mathrm{CH}_{3}\right)_{2} \mathrm{CHONa}$ & 95.8 & $200 \sim 206$ & $377.1586\left(\mathrm{C}_{18} \mathrm{H}_{23} \mathrm{~N}_{3} \mathrm{O}_{6}\right)$ & 377.1550 \\
\hline 18 & $\left(\mathrm{CH}_{3}\right)_{2} \mathrm{CHO}$ & $\mathrm{KOH}$ & 67.4 & 210 & $277.1313\left(\mathrm{C}_{15} \mathrm{H}_{19} \mathrm{NO}_{4}\right)$ & 277.1287 \\
\hline
\end{tabular}

* Structures are shown in Fig. 1. 
The reaction products were purified by chromatography on silica gel followed by crystallization from appropriate solvents. Yields, melting points and the molecular ion peaks by high resolution mass spectrum of 7-alkoxymitosanes are shown in Table 1. Furthermore, the same reaction could also be applied to an indolequinone. 1-Ethyl-3-hydroxymethyl-5-methoxy-2-methylindole-4,7-dione reacted with $i$-propanol to give 1-ethyl-3-hydroxymethyl-5-i-propoxy-2-methylindole-4,7-dione (18). These results suggest that the reaction may be applicable to the 7 -alkoxymitosenes and $o$-alkoxy-p-quinones. Such transalkoxylation was not known in mitomycin chemistry or in general quinone chemistry. As shown in Table 1, alcoholysis of 7-methoxymitosanes was found to be more efficient with a lower alcohol than with a higher alcohol. One of the reasons may be due to the fact that solubility of the base is higher in a lower alcohol than in a higher alcohol. The yields were not affected by the kind of the base. It is known that mitomycins $\mathrm{A}$ and $\mathrm{B}$ are subjected to decarbamoylation by the action of excess sodium methoxide and that the corresponding decarbamoylmitosanes are given. ${ }^{20)}$ But in the alcoholysis which is described in the present paper, no corresponding decarbamoylmitosane was obtained. It is wellknown that 7-methoxy or 7-amino groups on mitosane undergo selective hydrolysis by treatment with aqueous sodium hydroxide, and 7-hydroxymitosane is obtained, and that treatment of 7-methoxymitosane such as mitomycin A or B with methanolic amines yields the corresponding 7-aminomitosane. ${ }^{5)}$ The reactivities of the 7-position of mitomycins may be explained by the conjugation system of the quinone ring. In hydrolysis, aminolysis and alcoholysis at the 7-position of mitosanes, it is reasonable to assume that nucleophiles such as hydroxides, amines or alkoxides attack at $\mathrm{C} 7$ by MichAEL addition and then the original substituents on $\mathrm{C} 7$ are replaced by the shift of equilibrium. Thus, the amino group or methoxy group on $\mathrm{C} 7$ of the original mitosanes is lost as a leaving group. By conjugation of the quinoid system, 7-hydroxymitosane is acidic enough to make a salt with a weak base such as triethylamine. ${ }^{4)}$

The p.m.r. spectra of the resulting 7-alkoxymitosanes were compatible with these structures. The methyl protons of 7-methoxy on mitomycins $\mathrm{A}$ and $\mathrm{B}$ were assigned to $\delta 4.03 \mathrm{ppm}(3 \mathrm{H}, \mathrm{s})$ and $\delta 4.05$ ppm $(3 \mathrm{H}, \mathrm{s})$ respectively, while these peaks disappeared upon alcoholysis products and signals corresponding to newly introduced alkoxy protons were shown, at $\delta 1.33 \mathrm{ppm}(3 \mathrm{H}, \mathrm{t}, J=6.5 \mathrm{~Hz})$ and $\delta$ $4.93 \mathrm{ppm}(2 \mathrm{H}, \mathrm{q}, J=6.5 \mathrm{~Hz})$ in $\mathbf{1}$, and at $\delta 5.40 \mathrm{ppm}(2 \mathrm{H}, \mathrm{s})$ and $\delta 7.43 \mathrm{ppm}(5 \mathrm{H}, \mathrm{s})$ in 16 . The amino protons of the urethane group on these derivatives were assigned at $c a . \delta 5.2 \mathrm{ppm}(2 \mathrm{H}$, bs). In the i.r. spectra of these compounds, the carbonyl absorption of the urethane group was observed $c a .1720 \mathrm{~cm}^{-1}$. The mass spectra of these compounds gave the expected molecular ion peaks and produced fragmentation patterns similar to those of mitomycin A or B which were discussed in detail by VAN LEAR. ${ }^{6)}$

\section{Biological Activities}

Antibacterial activities of the 7-alkoxymitosanes obtained as above are shown in Table 2 as minimum inhibition concentrations (MIC) by using the agar dilution method. Most of the compounds showed very strong antibacterial activities against Gram-positive and Gram-negative bacteria. Generally, the activities of these compounds were greater against Gram-positive bacteria than against Gramnegative bacteria. This type of antibacterial activity of these compounds is a general characteristic for mitomycin antibiotics and their derivatives. Antibacterial activities decreased when the chain length of the 7-alkoxy group increased. The activities of 7-alkoxymitosanes were greater than those of the corresponding 7-alkylaminomitosanes. It is well-known that a substituent group at the 7-position of mitosane strongly influences the activities, since activities are affected by oxidation-reduction potential in 
Table 2. Antibacterial activities of 7-alkoxymitomycins.

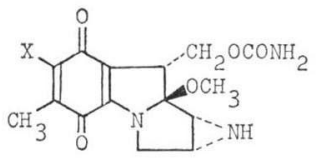

\begin{tabular}{|c|c|c|c|c|c|c|c|}
\hline \multirow{2}{*}{ No. } & \multirow{2}{*}{$\mathrm{X}$} & \multicolumn{6}{|c|}{$\mathrm{MIC}(\mathrm{mcg} / \mathrm{ml})^{*}$} \\
\hline & & (a) & (b) & (c) & (d) & (e) & (f) \\
\hline & $\mathrm{CH}_{3} \mathrm{O}$ & $<0.025$ & 0.196 & $<0.025$ & 0.098 & 0.391 & $<0.025$ \\
\hline 1 & $\mathrm{CH}_{3} \mathrm{CH}_{2} \mathrm{O}$ & $<0.025$ & 0.196 & $<0.025$ & 0.098 & 0.391 & $<0.025$ \\
\hline 2 & $\mathrm{CH}_{3} \mathrm{CH}_{2} \mathrm{CH}_{2} \mathrm{O}$ & $<0.025$ & 0.782 & $<0.025$ & 0.391 & 0.782 & $<0.025$ \\
\hline 3 & $\left(\mathrm{CH}_{3}\right)_{2} \mathrm{CHO}$ & $<0.025$ & 1.563 & $<0.025$ & 0.391 & 1.563 & 0.049 \\
\hline 4 & $\mathrm{CH}_{3}\left(\mathrm{CH}_{2}\right)_{3} \mathrm{O}$ & $<0.025$ & 3.125 & $<0.025$ & 1.563 & 1.563 & $<0.025$ \\
\hline 5 & $\left(\mathrm{CH}_{3}\right)_{2} \mathrm{CHCH}_{2} \mathrm{O}$ & $<0.025$ & 1.563 & $<0.025$ & 0.391 & 1.563 & $<0.025$ \\
\hline 6 & $\mathrm{CH}_{3} \mathrm{CH}_{2} \mathrm{CH}\left(\mathrm{CH}_{3}\right) \mathrm{O}$ & $<0.025$ & 3.125 & $<0.025$ & 1.563 & 3.125 & 0.049 \\
\hline 7 & $\mathrm{CH}_{3}\left(\mathrm{CH}_{2}\right)_{4} \mathrm{O}$ & $<0.025$ & 6.25 & $<0.025$ & 3.125 & 12.5 & 0.098 \\
\hline 8 & $\left(\mathrm{CH}_{3}\right)_{2} \mathrm{CHCH}_{2} \mathrm{CH}_{2} \mathrm{O}$ & $<0.025$ & 6.25 & $<0.025$ & 1.563 & 6.25 & 0.049 \\
\hline 9 & $\mathrm{CH}_{3}\left(\mathrm{CH}_{2}\right)_{5} \mathrm{O}$ & $<0.025$ & 25 & $<0.025$ & 12.5 & 25 & 0.391 \\
\hline 10 & $\mathrm{C}_{8} \mathrm{H}_{11} \mathrm{O}$ & $<0.025$ & 12.5 & $<0.025$ & 12.5 & 12.5 & 0.196 \\
\hline 11 & $\mathrm{CH}_{3}\left(\mathrm{CH}_{2}\right)_{6} \mathrm{O}$ & 0.049 & $>50$ & $<0.025$ & 25 & 50 & 0.391 \\
\hline 12 & $\mathrm{CH}_{3}\left(\mathrm{CH}_{2}\right)_{7} \mathrm{O}$ & $<0.025$ & $>50$ & $<0.025$ & $>50$ & $>50$ & 3.125 \\
\hline 13 & $\mathrm{CH}_{3}\left(\mathrm{CH}_{2}\right)_{9} \mathrm{O}$ & 0.196 & $>50$ & $<0.025$ & $>50$ & $>50$ & 25 \\
\hline 14 & $\mathrm{CH}_{3}\left(\mathrm{CH}_{2}\right)_{17} \mathrm{O}$ & 3.125 & $>50$ & 3.125 & $>50$ & $>50$ & 25 \\
\hline 15 & $\mathrm{CH}_{3} \mathrm{OCH}_{2} \mathrm{CH}_{2} \mathrm{O}$ & & & $<0.025$ & & & $<0.025$ \\
\hline 16 & $\mathrm{C}_{6} \mathrm{H}_{5} \mathrm{CH}_{2} \mathrm{O}$ & $<0.025$ & 3.125 & $<0.025$ & 0.782 & 1.563 & 0.049 \\
\hline & $\mathrm{NH}_{2}$ & 0.049 & 3.125 & $<0.025$ & 3.125 & 3.125 & $<0.025$ \\
\hline & $\mathrm{CH}_{3} \mathrm{NH}$ & $<0.025$ & 12.5 & $<0.025$ & 25 & 12.5 & $<0.025$ \\
\hline & $\mathrm{CH}_{3} \mathrm{CH}_{2} \mathrm{CH}_{2} \mathrm{NH}$ & $<0.025$ & 25 & $<0.025$ & $>50$ & 25 & 0.098 \\
\hline & $\left(\mathrm{CH}_{3}\right)_{2} \mathrm{CHNH}$ & $<0.025$ & $>50$ & $<0.025$ & 50 & $>50$ & 0.196 \\
\hline & $\mathrm{C}_{6} \mathrm{H}_{11} \mathrm{NH}$ & $<0.025$ & $>50$ & $<0.025$ & 25 & 25 & 0.196 \\
\hline
\end{tabular}

* (a) Staphylococcus aureus ATCC 6538P (b) Escherichia coli No. 26 (c) Bacillus subtilis ATCC 10707 (d) Shigella sonnei ATCC 6897 (e) Salmonella typhi ATCC 9992 (f) Klebsiella pneumoniae ATCC 10031

the quinone-hydroquinone system which is influenced to a marked degree by the 7-substituent. ${ }^{7)}$

Acute toxicity and antitumor activity of the 7-alkoxymitosanes are shown in Table 3. 7-Alkoxymitosanes with lower alkoxy group on $\mathrm{C} 7$ showed a greater toxicity in mice, while the toxicity of 7-alkoxymitosanes with higher alkoxy group on $\mathrm{C} 7$ decreased. All 7-alkoxymitosanes showed a strong inhibition on the growth of HeLa S-3 cells in vitro $\left(\mathrm{IC}_{50} ;<0.01 \sim 0.1 \mathrm{mcg} / \mathrm{ml}\right)$. Most of the 7-alkoxymitosanes suppressed the growth of transplanted Sarcoma-180 (solid type) in mice. 7-n-Propoxy-7-demethoxymitomycin $\mathrm{A}$ (2) was equal to mitomycin $\mathrm{C}$ in antitumor activity. A more detailed report on the antitumor activities of the 7-alkoxymitosanes will be published elsewhere.

\section{Experimental Section}

Melting points were determined on a Yanagimoto melting point apparatus and were uncorrected. Infrared spectra were determined in $\mathrm{KBr}$ disk on a Hitachi 215 spectrophotometer and nuclear magnetic resonance spectra were recorded on a Varian T-60 spectrometer using tetramethylsilane as an internal standard. Mass spectra were determined on a JEOL-OISG-2 mass spectrometer. Each compound 
Table 3. Biological activities of 7-alkoxymitosanes.

\begin{tabular}{c|c|c}
\hline Compounds & $\begin{array}{c}\mathrm{LD}_{50}(\mathrm{i} . \mathrm{p} .)^{* 1} \\
(\mathrm{mg} / \mathrm{kg})\end{array}$ & $\begin{array}{c}\text { Antitumor } \\
\text { activity*2 } \\
\text { (Sarcoma-180 } \\
\text { solid tumor) } \\
\text { (T/C) }\end{array}$ \\
\hline Mitomycin A & 2.1 & Toxic \\
Mitomycin C & 8.4 & $0.3 \sim 0.4$ \\
$\mathbf{1}$ & 2.9 & Toxic \\
$\mathbf{2}$ & 3.35 & 0.35 \\
$\mathbf{3}$ & 4.5 & 0.53 \\
$\mathbf{4}$ & 5.25 & 0.60 \\
$\mathbf{5}$ & 3.7 & 0.49 \\
$\mathbf{7}$ & 10.5 & 0.51 \\
$\mathbf{8}$ & 6.75 & 0.62 \\
$\mathbf{9}$ & 22.5 & 0.62 \\
$\mathbf{1 1}$ & 87.5 & Toxic \\
$\mathbf{1 2}$ & 95 & 0.45 \\
$\mathbf{1 3}$ & 87.5 & 0.61 \\
$\mathbf{1 6}$ & 5.94 & 0.61 \\
$\mathbf{1 7}$ & 9.75 & 0.82 \\
\hline $\mathbf{1 0}$ & &
\end{tabular}

*1 LD $_{50}$ was calculated by BEHRENS-KÄRBER method. Mice ( $d d Y$-strain, male) weighing $20 \pm$ $1 \mathrm{~g}$ were used and were observed for 2 weeks after injection (i.p.) of drugs.

*2 Mice (ddY-strain, male) weighing $19 \pm 1 \mathrm{~g}$ were used. The drug dose was one-sixth of each $\mathrm{LD}_{50}$. Other details of the antitumor test followed the paper described by Овозні ${ }^{8}$. showed i.r., p.m.r. and mass spectra compatible with its structure. Thin-layer chromatography on silica gel (Eastman Chromagram No 6061) with the solvent system $\mathrm{CHCl}_{3}-\mathrm{Me}_{2} \mathrm{CO}$ (1:1) was used for identification of the products and tracing of the reactions.

\section{7-Ethoxy-7-demethoxymitomycin A (1)}

To a stirred mixture of $100 \mathrm{mg}$ of mitomycin $\mathrm{A}$ and $10 \mathrm{ml}$ of ethanol at room temperature was added $240 \mathrm{mg}$ of $1.6 \% \mathrm{KOH}$ ethanol solution in portions over 30 minutes. After excess dry-ice was added to the reaction mixture, the precipitate was filtered off and the filtrate was evaporated under reduced pressure and the residue was subjected to gradient chromatography on silica gel with acetone-chloroform (0:1 1:1). From the main reddish-purple elution, $103 \mathrm{mg}(97.3 \%$ yield) of reddish-purple powder was obtained. It was crystallized from acetone as reddishpurple needles.

A similar method offered the following derivatives; $7-n$-butoxy (4) (69.6\% yield), $7-i$ butoxy (5) (75.4\% yield), 7-n-amyloxy (7) (49.7\% yield), 7-i-amyloxy (8) (71.7\% yield), 7-n-hexyloxy (9) (36.6\% yield), 7-n-heptyloxy (11) $(57.0 \%$ yield), 7-n-octyloxy (12) (56.1\% yield), 7-ndecanoyloxy (13) $(57.3 \%$ yield), 7-(2-methoxy)ethoxy (15) (48.8\% yield), and 7-benzyloxy-7demethoxymitomycin A (16) $(49.4 \%$ yield).

\section{7-i-Propoxy-7-demethoxymitomycin A (3)}

To a stirred mixture of $1 \mathrm{~g}$ of mitomycin $\mathrm{A}$ and $22.5 \mathrm{ml}$ of $i$-propanol was added $257 \mathrm{mg}$ of $18.7 \%$ sodium $i$-propoxide $i$-propanol solution in portions over 1 hour at room temperature. After excess dryice was added to the reaction mixture, the precipitate was filtered off and the filtrate was evaporated under reduced pressure and the residue was chromatographed on silica gel with acetone - chloroform (0:1 $1: 1)$ in a gradient fashion. From the main reddish-purple elution, $887.9 \mathrm{mg}(75.8 \%$ yield) of powder was obtained. It was crystallized from acetone as reddish-purple needles.

A similar method offered the following derivatives; 7-n-propoxy (2) $(85.7 \%$ yield), 7-sec-butoxy (6) (68.4\% yield), 7-cyclohexyloxy (10) $(27.8 \%$ yield) and 7-stearyloxy-7-demethoxymitomycin A (14) $(11.0 \%$ yield). In these compounds, only 14 was obtained when tetrahydrofuran was used as a solvent.

\section{7-i-Propoxy-7-demethoxymitomycin B (17)}

To a stirred mixture of $100 \mathrm{mg}$ of mitomycin B and $4.5 \mathrm{ml}$ of $i$-propanol was added $44 \mathrm{mg}$ of $12.7 \%$ sodium $i$-propoxide $i$-propanol solution in portions over 1 hour at room temperature. After excess dryice was added to the reaction mixture, the precipitate was filtered off and the filtrate was evaporated under reduced pressure and the residue was chromatographed on silica gel with acetone - chloroform $(0: 1 \sim$ $1: 1)$ in a gradient manner. From the principal purple colored fraction, $101 \mathrm{mg}$ ( $95.8 \%$ yield) of deeppurple powder was obtained. It was crystallized from acetone as deep-purple needles.

\section{1-Ethyl-3-hydroxymethyl-5-i-propoxy-2-methylindole-4,7-dione (18)}

To a stirred mixture of $200 \mathrm{mg}$ of 1-ethyl-3-hydroxymethyl-5-methoxy-2-methylindole-4,7-dione ${ }^{\theta)}$ and $20 \mathrm{ml}$ of $i$-propanol was added $150 \mathrm{mg}$ of saturated $\mathrm{KOH} i$-propanol solution in portions over 1 hour at room temperature. After excess dry-ice was added to the reaction mixture, the precipitate was filtered off and the filtrate was evaporated under reduced pressure. The residue was crystallized from ethanol 
and $150 \mathrm{mg}(67.4 \%$ yield $)$ of reddish-orange needles were obtained.

\section{Acknowledgments}

We would like to thank Miss Y. Adachi for the mass spectra, Mrs. K. YамAmoto for determining the antibacterial activity, Mr. T. Ashizawa for experimental assistance on the antitumor tests, and Dr. Y. Fusimoto and Mr. N. NAKAMURA for helpful discussions.

\section{References}

1) Hata, T.; Y. Sano, R. Sugawara, A. Matsumae, K. Kanamori, T. Shima \& T. Hoshi: Mitomycin, a new antibiotic from Streptomyces. 1. J. Antibiotics, Ser. A 9: $141 \sim 146,1956$

2) See, for example,

a) Wakaki, S.; T. Marumo, T. Tomioka, E. Shimizu, H. Kato, S. Kamada, S. Kudo \& Y. Fujimoto: Isolation of new-fractions of antitumor mitomycins. Antibiot. Chemother. 8: 228 240, 1958

b) Kinoshita, S.; K. Uzu, K. Nakano, M. Shimizu, T. Takahashi \& M. Matsui: Mitomycin derivatives. 1. Preparation of mitosane and mitosene compounds and their biological activities. J. Med. Chem. 14: 103 109, 1971

c) Kinoshita, S.; K. Uzu, K. Nakano \& T. Takahashi: Mitomycin derivatives. 2. Derivatives of decarbamoylmitosane and decarbamoylmitosene. J. Med. Chem. 14: 109 112, 1971

d) TAYLOR, W. G. \& W. A. Remers: Structure and stereochemistry of some 1,2-disubstituted mitosenes from solvolysis of mitomycin C and mitomycin A. J. Med. Chem. 18: 307 311, 1975

e) Yahashi, R. \& I. Matsubara: The molecular structure of 7-demethoxy-7-p-bromoanilinomitomycin B. J. Antibiotics 29: 104 106, 1976 (This paper was corrected partially in J. Antibiotics 31 (6): correction, 1978)

f) Kishi, Y.: Total synthesis of mitomycins. J. Natl. Pro. (Lloydia) 42: 549 568, 1979

g) NAKANO, K.: Synthesis and biological activities of mitomycin derivatives. Heterocycles 13: 373 387,1979 and references cited therein.

3) Webb, J. S.; D. B. Cosulich, J. H. Mowat, J. B. Patrick, R. W. Broschard, W. E. Meyer, R. P. Williams, C. F. Wolf, W. Fulmor, C. Pidacks \& J. E. Lancaster: The structures of mitomycin A, B and C and porfiromycin. 1. J. Am. Chem. Soc. 84: 3185 3187, 1962

4) Schroeder, W.: Porfiromycin derivatives and method of making same. U. S. Pat. 3,306,821, 1967

5) Matsui, M.; Y. Yamada, K. Uzu \& T. Hirata: Studies on mitomycins. 3. The synthesis and properties of mitomycin derivatives. J. Antibiotics 21: 189 198, 1968

6) VAN Lear, G. E.: Mass spectrometric studies of antibiotics. 1. Mass spectra of mitomycin antibiotics. Tetrahedron 26: 2587 2597, 1970

7) Kinoshita, S.; K. Uzu, K. Nakano, M. Shimizu, T. Takahashi, S. Wakaki \& M. Matsui: The chemical transformation of mitomycins: The structure-activity relationship of mitomycin derivatives. Progr. Antimicr. \& Anticancer Chemother. Vol. 2, pp. 1058 1068, 1970

8) Oboshi, S ; M Matsui, S. Ishi, N. Masago, S. Wakaki \& K. UzU: Antitumor studies on mitomycin derivatives. 2. Effect on solid tumor of Sarcoma-180. Gann 58: 315 321, 1967

9) Nakano, K.; N. Nishiyama, K. UzU \& S. Kinoshita: Studies on mitomycins. 5. Synthesis of indolequinone and their activities. J. Antibiotics 24: 435 442, 1971 